Article

\title{
Impact of Soil Chemical Properties on the Growth Promotion Ability of Trichoderma ghanense, T. tomentosum and Their Complex on Rye in Different Land-Use Systems
}

\author{
Danguolè Bridžiuvienè ${ }^{1}$, Vita Raudonienè ${ }^{1}$, Jurgita Švedienè ${ }^{1, * \mathbb{D}}$, Algimantas Paškevičius $^{1}$, Ieva Baužienè ${ }^{1}$, \\ Gintautas Vaitonis ${ }^{1}$, Alvyra Šlepetiene ${ }^{2}$ (D) Jonas Šlepetys ${ }^{2}$ and Audrius Kačergius ${ }^{2}$ (D) \\ 1 Nature Research Centre, 08412 Vilnius, Lithuania; danguole.bridziuviene@gamtc.lt (D.B.); \\ vita.raudoniene@gamtc.lt (V.R.); algimantas.paskevicius@gamtc.lt (A.P.); ieva.bauziene@gamtc.lt (I.B.); \\ gintautas.vaitonis@gamtc.lt (G.V.) \\ 2 Lithuanian Research Centre for Agriculture and Forestry, 58344 Akademija, Lithuania; \\ alvyra.slepetiene@lammc.lt (A.Š.); jonas.slepetys@lammc.lt (J.Š.); audrius.kacergius@lammc.lt (A.K.) \\ * Correspondence: jurgita.svediene@gamtc.lt
}

check for updates

Citation: Bridžiuvienè, D.; Raudonienè, V.; Švedienè, J.; Paškevičius, A.; Baužienè, I.; Vaitonis, G.; Šlepetienè, A.;

Šlepetys, J.; Kačergius, A. Impact of Soil Chemical Properties on the Growth Promotion Ability of Trichoderma ghanense, T. tomentosum and Their Complex on Rye in Different Land-Use Systems. J. Fungi 2022, 8, 85. https://doi.org/10.3390/ jof 8010085

Academic Editor: Samantha

C. Karunarathna

Received: 23 November 2021

Accepted: 13 January 2022

Published: 15 January 2022

Publisher's Note: MDPI stays neutral with regard to jurisdictional claims in published maps and institutional affiliations.

Copyright: (C) 2022 by the authors. Licensee MDPI, Basel, Switzerland. This article is an open access article distributed under the terms and conditions of the Creative Commons Attribution (CC BY) license (https:// creativecommons.org/licenses/by/ $4.0 /)$.

\begin{abstract}
Microbial-based biostimulants that increase plant performance and ensure sustainable restoration of degraded soils are of great importance. The aim of the present study was to evaluate the growth promotion ability of indigenous Trichoderma ghanense, T. tomentosum and their complex on early rye seedlings in sustained grassland and arable soil. The impact of soil chemical properties on the ability of selected Trichoderma strains and their complex to promote plant growth was determined by the evaluation of the rye (Secale cereale L.) early seedling growth-measuring the length of shoots and roots as well as their dry weight. Trichoderma species were tested for their ability to produce extracellular degradative enzymes on solid media. Furthermore, the soil properties and CM-cellulase activity of soil were estimated. The indigenous Trichoderma strains possess the capacity to produce enzymes such as peroxidase, laccase, tyrosinase, and endoglucanase. The results indicated a significant $(p<0.05)$ increase in plant growth and the improvement of some soil chemical properties (total $\mathrm{N}$, mobile humic and fulvic acids, exchangeable $\mathrm{K}_{2} \mathrm{O}$, soil CM-cellulase activity) in inoculated soils when compared to the control. The growth of the roots of rye seedlings in sustained grassland was enhanced when $T$. tomentosum was applied $(p=0.005)$. There was an increase in total weight and shoot weight of rye seedlings when T. ghanense was used in the arable soil $(p=0.014$ and $p=0.024$ ). The expected beneficial effect of Trichoderma spp. complex on rye growth promotion was not observed in any tested soil. The results could find application in the development of new and efficient biostimulants, since not only do physiological characteristics of fungi play an important role but also the quality of the soil has an impact.
\end{abstract}

Keywords: growth promotion; Trichoderma; physiological characteristics; CM-activity of soil

\section{Introduction}

Intensive farming, the abundant use of fertilizers - especially nitrogenous - and pesticides, and the prevalence of monocultures and intensive tilling have an unavoidable negative influence on soil microbiota and crop yield worldwide [1]. Microorganisms are responsible for the decomposition of organic matter in the soil and involved in the formation of humus, the improvement of soil quality and the supply of nutrients to plants. The demand for food for the growing human population is constantly increasing; the world will need $70-100 \%$ more food by 2050 . The production of cereals, especially wheat, rice, and maize, which account for half of human calorie intake, has to be increased [2]. Indeed, more sustainable agriculture requires yield increases and improved product quality, while reducing the negative impact of agrochemicals on the environment, all of which might be fostered by microbial-based biostimulants [3]. Microbial-based biostimulants have been 
important since the beginning of agriculture (i.e., Rhizobium in legumes). These biostimulants or biofertilizers increase plant performance and ensure the sustainable restoration of degraded soils [3-6]. Recently, biofertilizers have been produced from microorganisms that are able to mineralize organic matter in the soil or accumulate inorganic matter from the atmosphere, thus providing plants with nutrients. Moreover, some of them show plant growth promotion and biocontrol abilities $[5,7,8]$.

Fungi such as Trichoderma are often used as growth promotion agents and biofertilizers. Extensive research has been focused on their physiological and biological characteristics. They produce enzymes such as cellulase complex enzymes, xylanase, chitinase, amylase, and pectinase that enable the efficient decomposition of organic matter in the soil, thus providing plants with nutrients [9-12]. According to López-Bucio et al. [3], the best studied Trichoderma species regarding their mechanisms of action are T. asperullum, T. artoviride, T. harzianum, T. virens and T. viride, most of which also exhibit high biostimulant action on horticultural crops. The extracellular oxidoreductases produced by Trichoderma participate in the decomposition of phenolic compounds of both natural and xenobiotic substances, resulting in the object of soil bioremediation agents [13]. High growth rates and strong antagonistic abilities that are characteristic of many Trichoderma spp., allow their use as biocontrol agents against pathogenic fungi such as Botrytis, Fusarium, Rhizoctonia, Sclerotinia, etc. $[7,14,15]$. Moreover, fungi such as Trichoderma promote the growth of plant roots and shoots by solubilization of phosphates and micronutrients in soil [8,16]. Furthermore, there are reports on their ability to enhance plant tolerance to environmental stresses, such as drought or high salinity [17-19].

All of these characteristics make Trichoderma spp. a very promising agent to produce Trichoderma-based biostimulant products for the sustainable management of agriculture [20]. Much work has been invested in different technologies for biofertilizers, biopesticides, and biostimulants, as well as studies of their mechanisms [5,21,22]. Several Trichoderma-based product application methods have been developed for seeds, seedlings, plants, or soil treatment. Most Trichoderma-based products are used as biopesticides and little attention has been paid to Trichoderma as a biofertilizer or plant growth promoter. [23]. Moreover, not much study has been focused on inefficient products after field treatment [24]. The production of metabolites and the activity of enzymes of Trichoderma greatly depends on the environmental conditions. Therefore, the impact of Trichoderma-based products is expected to be different in soils of varying quality. A complex of soil environment properties unsuitable for the development of Trichoderma could explain cases where the use of fungal inoculants was inefficient [21]. Caporale et al. [25] discovered the different effects of arable, grove, and forest soils on the efficiency of two T. harzianum strains in promoting the growth of Brassica rapa. However, there have not been enough studies on the effect of Trichoderma spp. on plant growth promotion in different land-use systems. Soil is a variable and labile system; therefore, the fungi with appropriate physiological and biological characteristics are important for the creation of efficient bio-products. For that reason, deep studies of fungi in soils of varying quality are required. The aim of the present study was to evaluate the growth promotion ability of indigenous T. ghanense, T. tomentosum and their complex species on early rye seedlings in sustained grassland and arable soil.

\section{Materials and Methods}

\subsection{Fungi}

Two indigenous Trichoderma strains were used in this research. These two strains were isolated from winter rye (Secale cereale) rhizospheric soil of the Voke Branch of the Lithuanian Research Centre for Agriculture and Forestry (Vilnius, Lithuania) during the summer season of 2015. For Trichoderma isolation, the soil serial dilution plate method was used [26]. In brief, $10 \mathrm{~g}$ of soil sample was added into $90 \mathrm{~mL}$ of sterilized water and shaken on an orbital shaker at $200 \mathrm{rpm}$ for $1 \mathrm{~h}$. Immediately after shaking, a series of 10-fold dilutions of the suspension were carried out, and appropriate dilutions were plated on malt extract agar with chloramphenicol $\left(250 \mathrm{mg} \mathrm{L}^{-1}\right)$. The plates were incubated at $28{ }^{\circ} \mathrm{C}$ 
for 5 days. Individual colonies of fungi were isolated, purified and maintained on potato dextrose agar (PDA; Oxoid, Basingstoke, Hampshire, UK) slants at $4{ }^{\circ} \mathrm{C}$.

\subsection{Identification of Fungi}

The identification of fungi was based on morphological characteristics, internal transcribed spacer (ITS) region and translation elongation factor 1 alpha (TEF1) gene sequence analysis $[27,28]$.

The microscopy observation of Trichoderma spp. was performed using a Leica DM5000 microscope with a Leica DFC450 camera mounted on top. Trichoderma spp. morphology was examined from cultures grown on MEA at $28^{\circ} \mathrm{C}$ for 5 days.

For genomic DNA, approximately $100 \mathrm{mg}$ wet weight of mycelium was extracted from fresh cultures grown on malt extract agar (MEA, Liofilchem, Roseto d. Abruzzi (TE), Italy) with ZR Fungal/Bacterial DNA MiniPrep ${ }^{\mathrm{TM}}$ Kit (Zymo Research Europe GmbH, Freiburg im Breisgau, Germany) following the manufacturer's instructions. The internal transcribed spacers 1 and 2 of rDNA, including the 5.8S rDNA, were amplified using primers ITS5 [29] and AscoITS4 [30], and the region of translation elongation factor $1 \alpha$ (TEF1) was amplified using primers EF-1 and EF-2 [31].

The PCR was performed in a Veriti-96 Gradient Thermocycler (Applied Biosystems, Waltham, MA, USA) in $20 \mu \mathrm{L}$ volume applying $10 \mu \mathrm{L}$ KAPATaq Ready Mix (KAPAbiosystems, Wilmington, DE, USA) according to the manufacturer's instructions. Sequencing of purified PCR products was performed by BaceClear B.V. (Leiden, The Netherlands). From each specimen, two different PCR products were sequenced in both directions ( $5^{\prime}$ and $\left.3^{\prime}\right)$ using the same primers used in the amplification reactions. The Basic Local Alignment Sequence Tool for nucleotides (BLASTn) search program (NCBI) performed the rDNA homology searches. All sequences are available at the National Center for Biotechnology Information (NCBI) GenBank under the accession numbers OL892052/MW829414 and OL892051/MW829415. The phylogenetic analyses were conducted in MEGA 11 [32] using the maximum parsimony method applying the subtree-pruning-regrafting (SPR) algorithm with search level 1 , in which the initial trees were obtained by the random addition of sequences (5 replicates). The trees were drawn to scale, with branch lengths calculated using the average pathway method and were in the units of the number of changes over the whole sequence [33]. The percentage of replicate trees in which the associated taxa clustered together in the bootstrap test (1000 replicates) are shown next to the branches [34].

\subsection{Trichoderma spp. Physiological Characteristics}

Trichoderma fungi were tested for their ability to produce extracellular degradative enzymes (peroxidase, laccase, tyrosinase, and endoglucanase) on solid media. Additionally, the change in lignin and cellulose content in the straw was recorded.

Flasks of $50 \mathrm{~mL}$ were filled with $0.5 \mathrm{~g}$ of the rye (Secale cereale) straw, which was grounded into particle sizes of $2-4 \mathrm{~mm}$ and sterilized by autoclave. After sterilization, the straw was moistened with a sterile mineral solution ( $3 \mathrm{~mL}$ per flask). Mineral solution: $\mathrm{NH}_{4} \mathrm{NO}_{3} 3 \mathrm{~g} \mathrm{~L}^{-1}$ and $\mathrm{KH}_{2} \mathrm{PO}_{4} 1 \mathrm{~g} \mathrm{~L}^{-1}$. Each flask was inoculated with a 9-mm disc of fungal mature culture (one disc per flask), and solid-state fermentation was maintained at $28^{\circ} \mathrm{C}$ for 30 days. The flasks without fungi were used as a control. All experiments were performed in triplicate.

Enzymatic assay of peroxidase (E.C. 1.11.1.7) was based on the colorimetric evaluation of the oxidation product of o-dianisidine in the presence of $\mathrm{H}_{2} \mathrm{O}_{2}$ [35]. The reaction mixture contained $0.5 \mathrm{~mL}$ of cultural liquid, $3 \mathrm{~mL}$ of o-dianisidine reagent $(50 \mathrm{~mL} 0.4 \mathrm{M}$ phosphate buffer (pH 5.9), $2 \mathrm{~mL}$ of $1 \%$ o-dianisidine, $200 \mathrm{~mL}$ of distilled water), and $0.2 \mathrm{~mL}$ of $0.05 \%$ $\mathrm{H}_{2} \mathrm{O}_{2}$. Tests and controls were incubated at $20^{\circ} \mathrm{C}$ for $5 \mathrm{~min}$ in a water bath. The reaction was stopped by addition of $50 \% \mathrm{H}_{2} \mathrm{SO}_{4}$. Absorbance of the reaction mixtures was measured at $560 \mathrm{~nm}$ using an Evolution 60S spectrophotometer (ThermoFisher Scientific, Waltham, MA, USA). The activity of peroxidase was calculated according to the coefficient of micromolar 
extinction, with the value of 0.0128 . Peroxidase activity was expressed as activity units (a.u.) $\mathrm{g}^{-1}$.

Enzymatic assay of laccase (E.C. 1.10.3.2.) was conducted according to Ravin and Harward [36] methodical recommendations. The reaction mixture contained $0.1 \mathrm{~mL}$ of cultural liquid, $1 \mathrm{~mL} 0.5 \%$ of p-phenylenediamine hydrochloride, and $2 \mathrm{~mL} 0.1 \mathrm{~N}$ of acetate buffer ( $\mathrm{pH}$ 6). The reaction was stopped by adding $1 \mathrm{~mL} 0.1 \%$ of sodium azide solution. Absorbance of the reaction mixtures was measured at $530 \mathrm{~nm}$ using an Evolution $60 \mathrm{~S}$ spectrophotometer (ThermoFisher Scientific, Waltham, MA, USA). Laccase activity was expressed as activity units (a.u.) $\mathrm{g}^{-1}$.

Enzymatic assay of tyrosinase (E.C. 1.10.3.1.) measured absorbance spectrophotometrically using a method based on the estimation of the optical density of reaction products formed during oxidation of pyrocatechin over a given period [37]. The reaction mixture contained $0.5 \mathrm{~mL}$ of cultural liquid, $2 \mathrm{~mL} 0.06 \mathrm{M}$ of phosphate buffer ( $\mathrm{pH} 7.4$ ), and $0.5 \mathrm{~mL}$ $0.05 \mathrm{M}$ of pyrocatechin. Absorbance of the reaction mixtures was measured at $420 \mathrm{~nm}$ using an Evolution 605 spectrophotometer (ThermoFisher Scientific, Waltham, MA, USA). Indications of the spectrophotometer were recorded every $20 \mathrm{~s}$ for $2 \mathrm{~min}$. Tyrosinase activity was expressed as conditional units (c.u.) $\mathrm{g}^{-1}$.

Enzymatic assay of endoglucanase (E.C. 3.2.1.4) was estimated with Na-carboxymethylcellulose (Na-CMC) [35]. One $\mathrm{ml}$ of $1 \% \mathrm{Na}-\mathrm{CMC}$ was placed in a test tube containing $1 \mathrm{~mL}$ of a cultural liquid and incubated at $40^{\circ} \mathrm{C}$ for $30 \mathrm{~min}$. After incubation, endoglucanase activity was estimated according to the amount of the reducible substance in $1 \mathrm{~mL}$ of the reaction compound using an o-toluidine reagent. The reaction mixture containing $1 \mathrm{~mL}$ of cultural liquid and $7 \mathrm{~mL}$ of o-toluidine reagent was boiled for $10 \mathrm{~min}$. The amount of glucose was measured at $560 \mathrm{~nm}$ with an Evolution 60S (ThermoFisher Scientific, Waltham, MA, USA). The amount of reducible substance was estimated according to the glucose calibration curve. Endoglucanase activity was expressed in percent (\%).

The content of lignin in the rye straw was evaluated following the method of Chudiakova [38]. For the estimation of lignin degradation, after incubation, $0.5 \mathrm{~g}$ of rye straw was placed in $300 \mathrm{~mL}$ flasks containing $60 \mathrm{~mL}$ of $2 \% \mathrm{HCl}$ and was boiled for $2 \mathrm{~h}$. The content was filtered, washed with water until the acid reaction ceased, and then was washed with acetone until the filtrate became clear. The rye straw was dried and transferred into $7 \mathrm{~mL}$ of $72 \% \mathrm{H}_{2} \mathrm{SO}_{4}$. Hydrolysis was continued for $2.5 \mathrm{~h}$ at $20{ }^{\circ} \mathrm{C}$ with periodic shaking. Then, $93 \mathrm{~mL}$ of water was added into each flask and the content boiled for $1 \mathrm{~h}$ after fitting with a return condenser. After filtration, the filtrate was washed with $\mathrm{NaCl}$ solution $\left(0.5 \mathrm{~g} \mathrm{~L}^{-1}\right)$ to eliminate acid. The filter with lignin was dried at $105^{\circ} \mathrm{C}$ for $4 \mathrm{~h}$ and weighed. The loss of lignin (\%) was determined by comparison to the corresponding content in the control rye straw.

The content of cellulose in the rye straw was evaluated following Kürschner's and Hafer's method [37]. The method is based on the oxidation, decomposition, and dissolution of various phenolic compounds of the plant. Cellulose remains unchanged. After incubation, $0.5 \mathrm{~g}$ of rye straw was placed in $300 \mathrm{~mL}$ flasks containing a $30 \mathrm{~mL}$ mixture of $\mathrm{HNO}_{3}$ and $\mathrm{C}_{2} \mathrm{H}_{5} \mathrm{OH}$ (using ratio 1:4) and boiled for $1 \mathrm{~h}$. The content was filtered and washed with pure ethanol. After filtration, the rye straw was dried and transferred into flasks containing $50 \mathrm{~mL}$ of $0.3 \mathrm{M} \mathrm{NaOH}$ and boiled for $1 \mathrm{~h}$ after fitting with a return condenser. After filtration, the filtrate was washed with $\mathrm{H}_{2} \mathrm{O}$, dried at $105^{\circ} \mathrm{C}$ for $4 \mathrm{~h}$, and weighed. The loss of cellulose (\%) was determined by comparing the corresponding content in the control rye straw.

The colony growth rates of Trichoderma spp. at different $\mathrm{pH}(4 ; 5 ; 6 ; 7$ and 8$)$ values were tested on Czapek Dox agar (CzDA, Liofilchem, Italy) and at several temperatures-5, 15,26 , and $35^{\circ} \mathrm{C}$ - on PDA. The mycelial growth was measured after 5 days of incubation. All experiments were performed in triplicate. 


\subsection{Soil Sampling and Analysis}

Samples taken from the top layer $(0-25 \mathrm{~cm})$ of soil developed by two different land-use systems — soil from sustained grassland (1S) and arable soil (crop rotation field) (2S) —were used for the experiment. Both investigated topsoil horizons were identified as Eutric Endocalcaric Endostagnic Cambisol on light loam of glacial moraine.

Grassland $1 S$ was a pasture with a mixture of grasses and leguminous herbs sown in 1945. The pasture has been used for 74 years without reseeding. Currently, the pastureformed grassland is semi-natural, dominated by grasses.

Arable soil 2S had been in ecological crop rotation since 2003. Crop rotation three-field: 1-winter wheat, 2-summer barley with red clover under sowing, and 3-red clover for seed. The soil sample was collected after winter wheat cultivation.

Before the experiment, the chemical properties and CM-cellulase activity of the original soil samples were evaluated. The chemical analysis of soil was performed at the Chemical Research Laboratory of the Lithuanian Research Centre for Agriculture and Forestry (Table 1).

Table 1. Chemical properties of original soil samples.

\begin{tabular}{|c|c|c|c|}
\hline Chemical Properties & Grassland & Arable Soil & Methods \\
\hline $\begin{array}{l}\text { Soil organic carbon } \\
\text { (SOC), \% }\end{array}$ & 2.49 & 1.43 & $\begin{array}{l}\text { Spectrophotometric measurement } \\
\text { method at } 590 \text { nm using glucose as a } \\
\text { standard after wet combustion [39]. }\end{array}$ \\
\hline Humus, $\%$ & 4.30 & 2.46 & $\begin{array}{l}\text { Calculated using conversion factor } \\
\text { (1.724) from SOC. }\end{array}$ \\
\hline Total N (Nt), \% & 0.115 & 0.080 & $\begin{array}{l}\text { Kjeldahl method using a } \\
\text { spectrophotometric measurement at } \\
655 \mathrm{~nm} \text {. }\end{array}$ \\
\hline $\mathrm{C} / \mathrm{N}$ & 21.70 & 17.90 & Calculation as ratio of SOC to $\mathrm{Nt}$. \\
\hline $\begin{array}{l}\text { Exchangeable } \mathrm{P}_{2} \mathrm{O}_{5}, \\
\mathrm{mg} / \mathrm{kg}\end{array}$ & 46.90 & 97.70 & A-L method. \\
\hline $\begin{array}{l}\text { Exchangeable } \mathrm{K}_{2} \mathrm{O}, \\
\mathrm{mg} / \mathrm{kg}\end{array}$ & 98.81 & 162.90 & A-L method. \\
\hline $\begin{array}{l}\text { Labile water-soluble } \\
\text { carbon, } \mathrm{C}_{\mathrm{H} 2 \mathrm{O}}, \mathrm{g} / \mathrm{kg}\end{array}$ & 0.299 & 0.106 & $\begin{array}{l}\text { Determined by IR detection after } \\
\text { UV-catalyzed persulfate } \\
\text { oxidation [40]. }\end{array}$ \\
\hline $\begin{array}{l}\text { Mobile humic substances, } \\
\text { (MHS) \% }\end{array}$ & 0.383 & 0.194 & Extracted with $0.1 \mathrm{M} \mathrm{NaOH}$ [41]. \\
\hline Mobile humic acids, $\%$ & 0.168 & 0.092 & Determined in $0.1 \mathrm{M} \mathrm{NaOH}$ extract. \\
\hline Mobile fulvic acids, $\%$ & 0.215 & 0.102 & Determined in $0.1 \mathrm{M} \mathrm{NaOH}$ extract. \\
\hline $\mathrm{pH}$ & 6.92 & 6.83 & $\begin{array}{l}\text { Determined by the potentiometric } \\
\text { method in } 1 \mathrm{M} \mathrm{KCl}(1: 2.5, w / v) \text { extract. }\end{array}$ \\
\hline $\begin{array}{l}\text { CM-cellulase activity, } \mu \mathrm{g} \\
\mathrm{GE} \mathrm{g}^{-1} \cdot \mathrm{dm} \cdot 24 \mathrm{~h}^{-1}\end{array}$ & 456.70 & 100.40 & $\begin{array}{c}\text { Determined by the spectrophotometric } \\
\text { method [42]. }\end{array}$ \\
\hline
\end{tabular}

During the experiment (the original soil and soil after inoculation), the number of fungi was determined by the soil serial plate method [26]. The diluted samples were directly plated onto malt extract agar with chloramphenicol $\left(250 \mathrm{mg} \mathrm{L}^{-1}\right)$. Plates were incubated at $26^{\circ} \mathrm{C}$ for $2-5$ days, and the total colony-forming units (CFU) of each repetition were counted. All experiments were repeated in triplicate.

\subsection{The Estimation of CM-Cellulase Activity of Soil}

Ten grams of field-moist soil were placed into three $100 \mathrm{~mL}$ flasks. Then, $15 \mathrm{~mL}$ of $0.7 \% \mathrm{Na}-\mathrm{CMC}$ and $15 \mathrm{~mL}$ of $2 \mathrm{M}$ of acetate buffer were added to two flasks (samples). 
For the control, only $15 \mathrm{~mL}$ of acetate buffer was added into the third flask. The flasks were incubated at $50{ }^{\circ} \mathrm{C}$ for $24 \mathrm{~h}$. The samples were filtered immediately after incubation, and $0.5 \mathrm{~mL}$ of filtrates were diluted to $20 \mathrm{~mL}$ with distilled water in test tubes. One $\mathrm{ml}$ of diluted filtrate, $1 \mathrm{~mL}$ of reagent $\mathrm{A}$ (16 $\mathrm{g}$ of anhydrous sodium carbonate and $0.9 \mathrm{~g}$ of potassium cyanide in $1000 \mathrm{~mL}$ of distilled water), and $1 \mathrm{~mL}$ of reagent $\mathrm{B}(0.5 \mathrm{~g}$ of potassium hexacyanoferrate (III) in a $1000 \mathrm{~mL}$ of distilled water) were added into a test tube, sealed, and incubated for $15 \mathrm{~min}$ in a boiling water bath.

After cooling, $5 \mathrm{~mL}$ of reagent $\mathrm{C}$ (1.5 $\mathrm{g}$ of ferric ammonium sulphate, $1 \mathrm{~g}$ of sodium dodecyl sulphate, and $4.2 \mathrm{~mL}$ of concentrated $\mathrm{H}_{2} \mathrm{SO}_{4}$ in $1000 \mathrm{~mL}$ of distilled water) was added. Absorbance of the reaction mixtures was measured at $690 \mathrm{~nm}$ using an Evolution 60S spectrophotometer (ThermoFisher Scientific, Waltham, MA, USA). CM-cellulase activity of soil was expressed as $\mu \mathrm{g}$ of glucose equivalents (GE) per gram dry matter and incubation time $\left(\mu \mathrm{g} \mathrm{GE} \mathrm{g}^{-1} \cdot \mathrm{dm} \cdot 24 \mathrm{~h}^{-1}\right)$ [42].

\subsection{Design of Experiment}

Plant pots ( $11 \mathrm{~cm}$ in diameter, $0.5 \mathrm{~L}$ volume) were filled loosely with non-sterilized grassland $1 S$ or arable soil $2 \mathrm{~S}$. For inoculum, the fungi were cultivated on PDA at $26{ }^{\circ} \mathrm{C}$ for 7 days. Suspensions of Trichoderma spp. were prepared in $0.9 \%$ saline from fully mature cultures. The concentration of the suspensions was determined by measuring the optical density at $530 \mathrm{~nm}$ with an Evolution 60S (Thermo Fisher Scientific, Waltham, MA, USA) and then checked by plating on PDA. The final inoculum concentrations were $1 \times 10^{9}$ conidia $\mathrm{ml}^{-1}$. Three milliliters of the inoculum were added into each pot and mixed well with the soil.

Three experiment variants were designed: first, using soil inoculated with Trichoderma tomentosum; second, with T. ghanense; and third, with the complex of T. tomentosum + T. ghanense. The non-inoculated soil of both qualities served as control. Every variant was performed in triplicate. Plant pots were incubated at $23{ }^{\circ} \mathrm{C}$ for 14 days in an environmental chamber (Climaslab 470, Barcelona, Spain). The required soil moisture was maintained during all experiments. After 14 days, the chemical properties and CM-cellulase activity of soil were estimated in every pot. Then, all inoculated pots and non-inoculated controls were used to test the effect of indigenous Trichoderma species on early seedling growth following standard ISO 11269-2:2012 [43]. Rye seeds (Secale cereale L.) with 96\% seed germination rate were used throughout this experiment. Twelve seeds of rye per pot were sowed at a depth of $5 \mathrm{~mm}$ and were placed in an environmental chamber (Climaslab 470, Barcelona, Spain) at $23{ }^{\circ} \mathrm{C}$ applying $16 \mathrm{~h}$ illumination period followed by $8 \mathrm{~h}$ darkness. After germination, the seedlings were thinned by leaving evenly 7 in every pot. After 14 days, the rye was harvested. The length of roots and shoots was measured, and the dry weight of seedling roots and shoots was estimated.

\subsection{Statistical Analysis}

The data on the root length, shoot length, and dry weight were analyzed using main effects ANOVA with treatment (control, I, II, and III). The soil (control, grassland, and arable soil) was used as categorical predictor. Hotelling's $\mathrm{T}^{2}$ was used for multivariate testing. Thereafter, significant factors were used for ANOVA analysis and Tukey's HSD for post hoc comparisons. Statistical analysis was performed using PAST3 software. Principal component analysis (PCA) was applied for soil properties. The results were evaluated by numerical methods after data transformation by centering: ( $x$-mean)/stdev. The confidence level was set as $p<0.05$. Using Microsoft Excel, statistical $t$ values were calculated for determination of variable significance.

\section{Results}

\subsection{Identification of Trichoderma and Their Physiological Characteristics}

Morphological features were used to classify the species of Trichoderma. The isolates had fast growing hyaline, later becoming green due to conidium production, colonies, and 
repeatedly branched conidiophores bearing flask-shaped phialides. According to these morphologic characteristics, the isolates were assigned to Trichoderma genus (Figure 1).
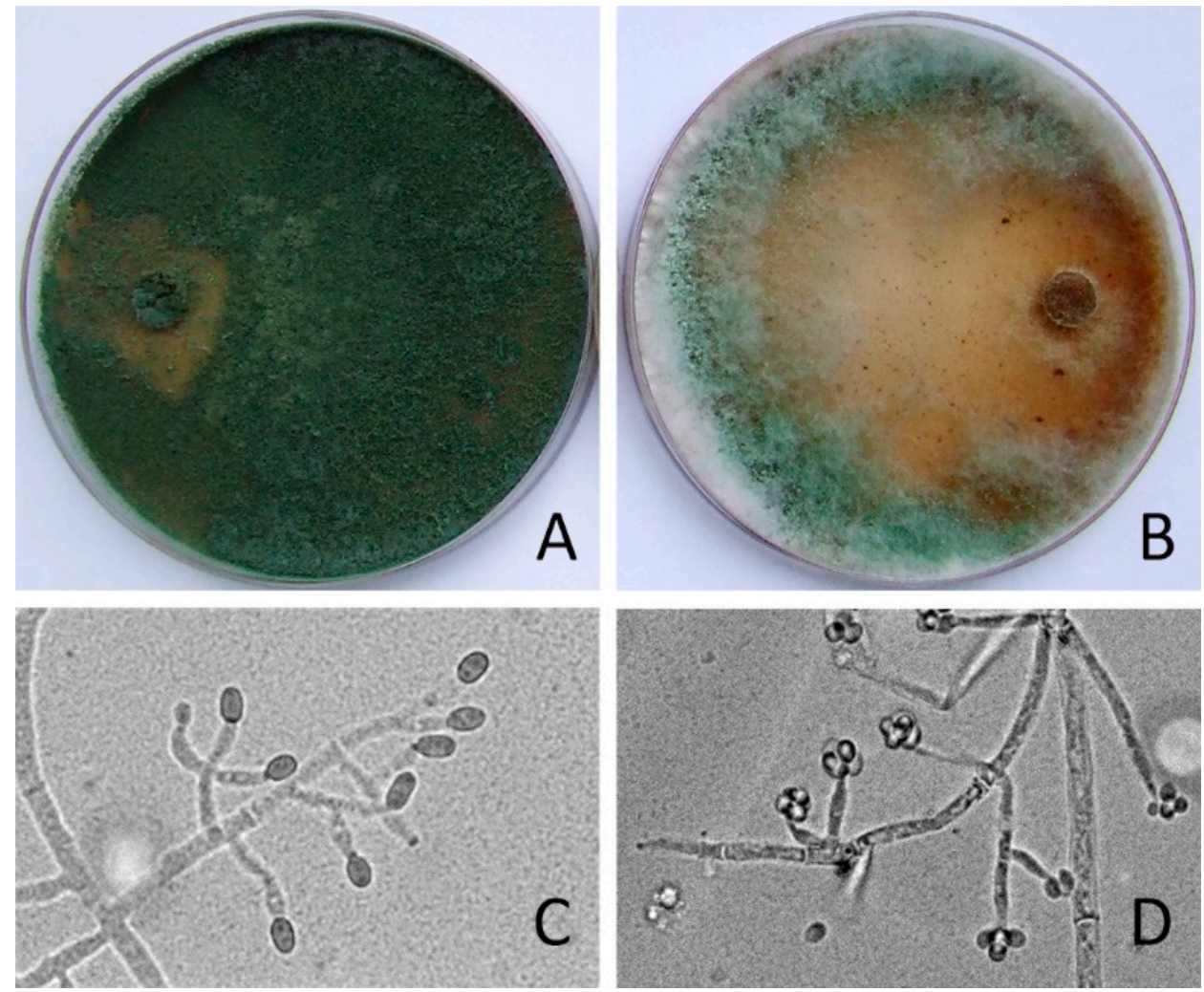

Figure 1. Macromorphology and micromorphology of Trichoderma strains on MEA after 7 days. (A)T. ghanense colony and (C) — conidiophores and conidia. (B) - T. tomentosum colony and (D)—conidiophores and conidia. Magnification $\times 400$.

Based on phylogenetic analysis of the ITS region and Tef- $1 \alpha$ gene, these fungal isolates were identified as T. ghanense Yoshim. Doi, Y. Abe and Sugiy and T. tomentosum Bissett. Comparison of the ITS and TEF1 gene sequences of our Trichoderma isolates with sequences of other, closely related Trichoderma accessions deposited in GenBank showed significant similarities (99-99.8\%) (Tables 2 and 3).

Table 2. Characterization of Trichoderma strains according to ITS region differences.

\begin{tabular}{|c|c|}
\hline Strain & Sequence Area Characterization \\
\hline & 281 \\
\hline T. tomentosum $\mathrm{T} 1$ & $5^{\prime} \cdot \cdot$ TCTGGATCGATGAAGAACGCAGCGAAATGCGATAATAATGTGAATTGCAGAATTCAGTG \\
\hline T. tomentosum AY605737 & $5^{\prime} \cdot$. TCTCGATCGATGAAGAACGCAGCGAAATGCGATACGTAATGTGAATTGCAGAATT \\
\hline T. ghanense $\mathrm{T} 2$ & 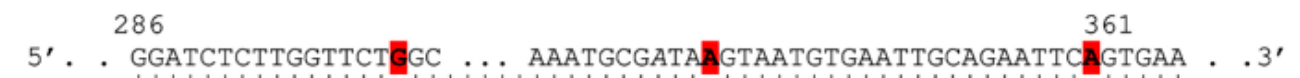 \\
\hline T. ghanense EU280100 & $5^{\prime}$. . GGATCTCTTGGTTCTCGC .... TGAAGAACTA_GTAATGTGAATTGCAGAATTCDGTGAA \\
\hline
\end{tabular}


Table 3. Characterization of Trichoderma strains according to TEF1 gene region differences.

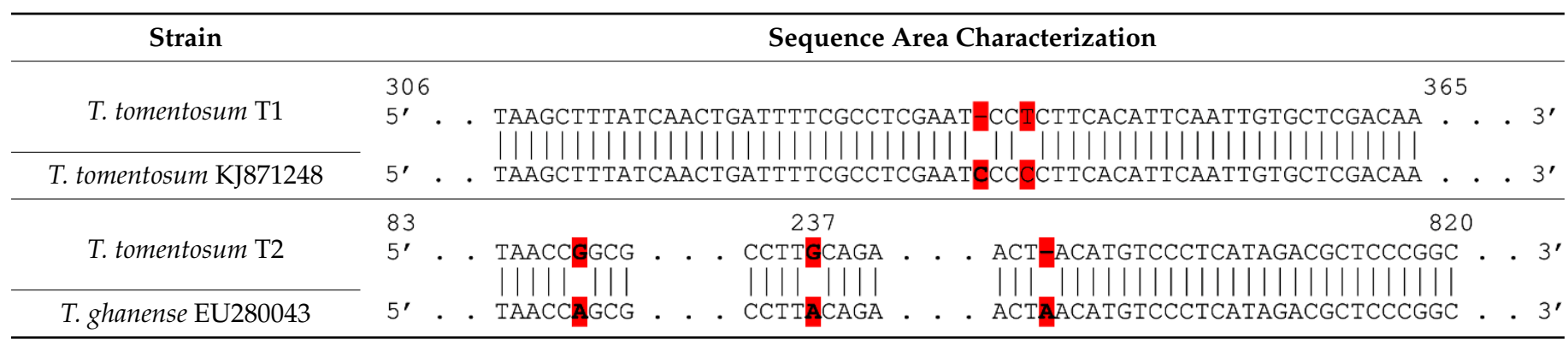

The phylogenetic analysis was conducted using the maximum parsimony likelihood method and Tamura-Nei model [32]. One of the most parsimonious trees (MP) of each analyzed locus is shown in Figure 2. The consistency index, the retention index for all sites, and length of tree are shown on the phylograms. The percentage $(>50 \%)$ of replicate trees in which the associated taxa clustered together in the bootstrap test (1000 replicates) is shown next to the branches.

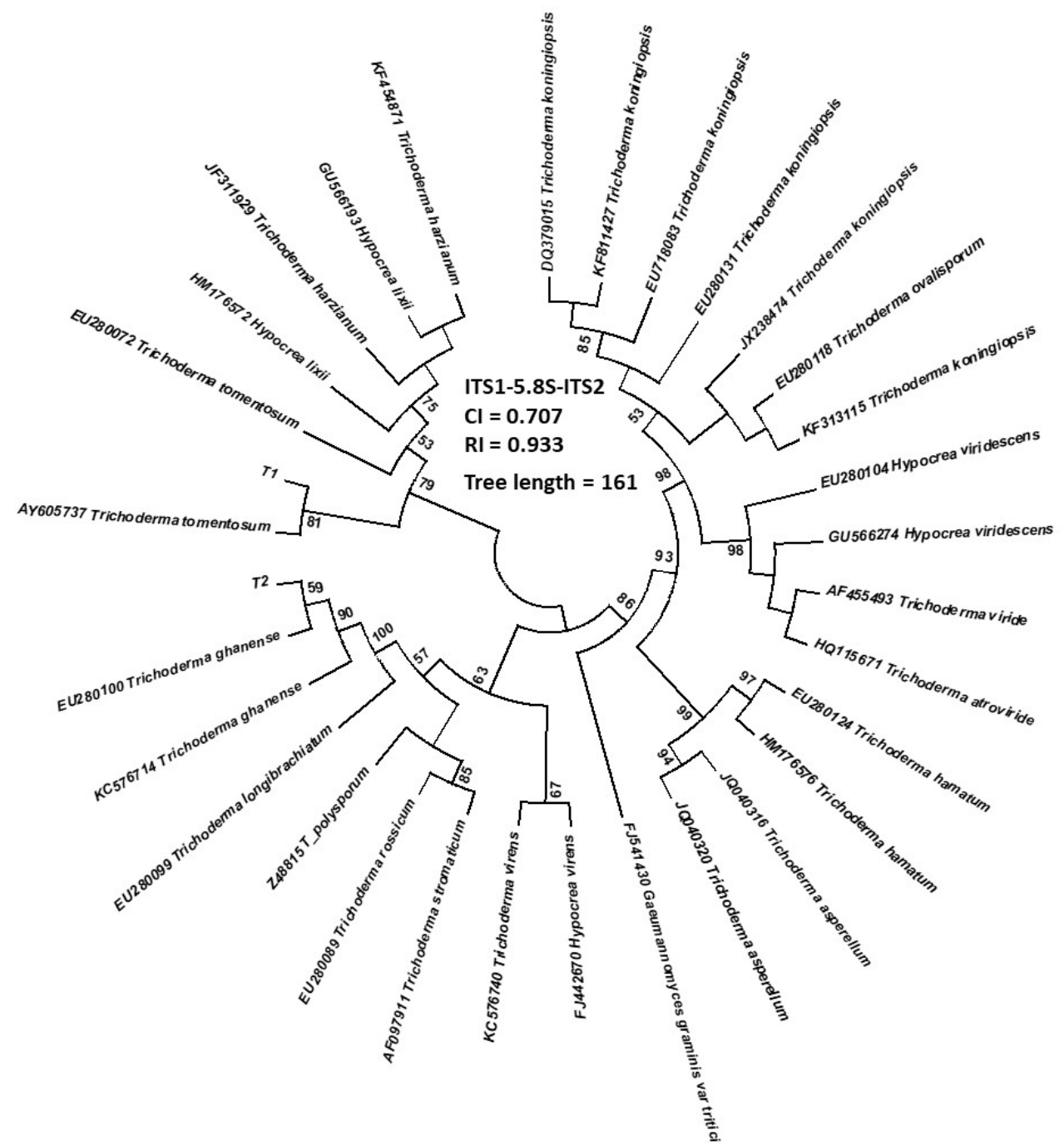

Figure 2. Cont. 


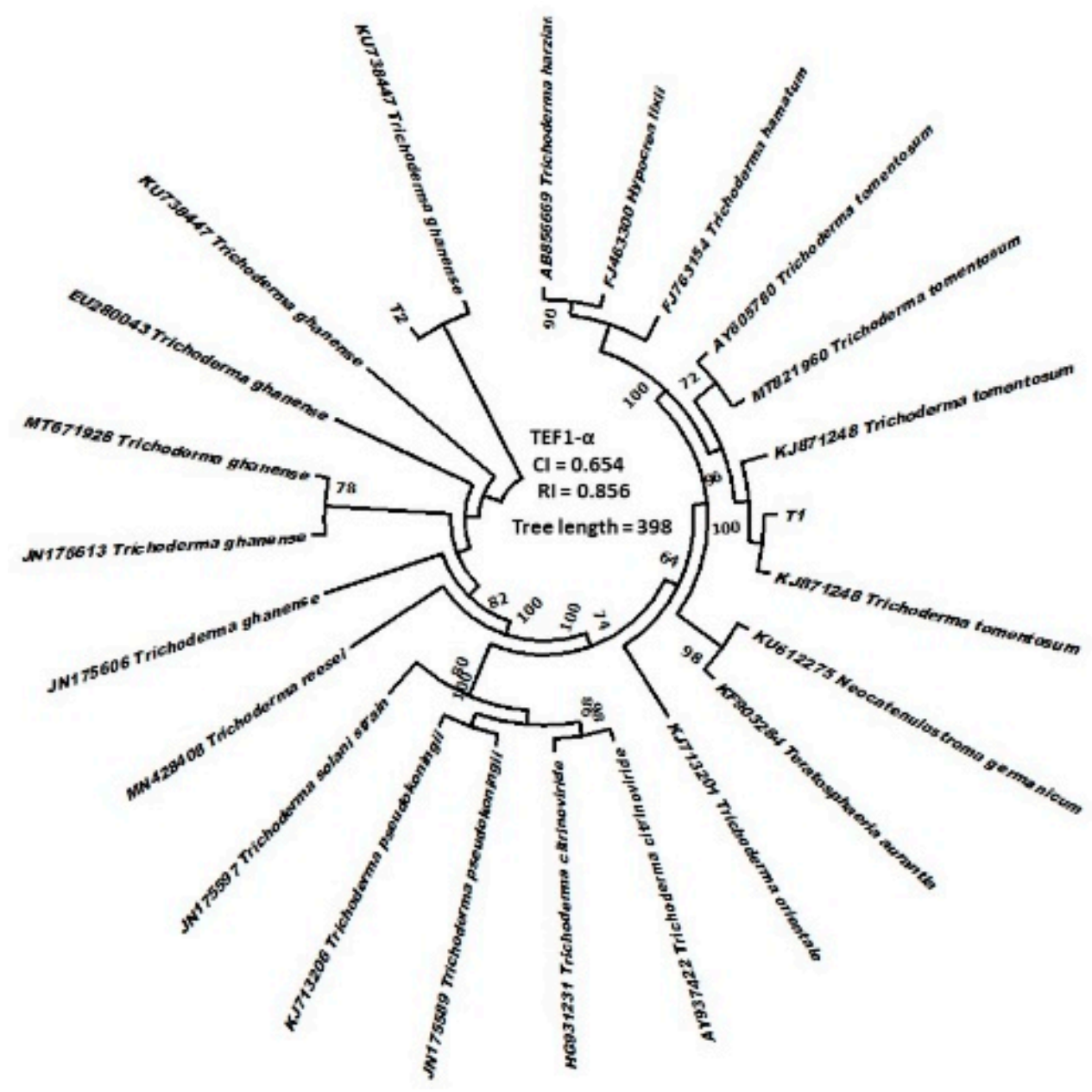

Figure 2. Phylogeny of Trichoderma isolates based on ITS1-5,8S-ITS2 and TEF1 loci. The most parsimonious tree for each locus with appropriate length is shown. CI-consistency index, RI-retention index. The percentage $>50 \%$ of replicate tree is shown next to branches.

The Trichoderma strains had different physiological characteristics. Both Trichoderma strains grew at a temperature in the range of 5 to $35^{\circ} \mathrm{C}$ (Table 4 ). At the temperature of $35^{\circ} \mathrm{C}, \mathrm{T}$. ghanense had higher growth rates than T. tomentosum; a significant difference was observed $(p=0.002)$, but at the temperature of $15^{\circ} \mathrm{C}$, the colony of T. tomentosum was larger $(p=0.00004)$. Significant differences were observed in colony growth rates of Trichoderma spp. at different $\mathrm{pH}(4,5,6,7$, and 8$)$ values. T. ghanense was less sensitive to medium $\mathrm{pH}$ changers, and T. tomentosum grew better in more acidic media.

Table 4. Physiological characteristics of Trichoderma ghanense and T. tomentosum. ${ }^{*}$ above the numbers indicate significant differences $(p<0.05)$.

\begin{tabular}{ccc}
\hline Physiological Characteristics & T. ghanense & T. tomentosum \\
\hline Growth (diameter, mm) on PDA at $7{ }^{\circ} \mathrm{C}$ & $5.0 \pm 0.0$ & $5.0 \pm 0.0$ \\
\hline $15^{\circ} \mathrm{C}$ & $37.0 \pm 1.7^{*}$ & $43.2 \pm 2.4^{*}$ \\
\hline $26^{\circ} \mathrm{C}$ & $46.6 \pm 2.3^{*}$ & $45.1 \pm 1.7^{*}$ \\
\hline $35^{\circ} \mathrm{C}$ & $56.2 \pm 2.3^{*}$ & $50.0 \pm 0.0^{*}$ \\
\hline $\begin{array}{c}\text { Growth (diameter, } \mathrm{mm} \text { ) on CzDA at } \\
26^{\circ} \mathrm{C} \text { and } \mathrm{pH} 4\end{array}$ & $55.0 \pm 0.0^{*}$ & $73.7 \pm 0.5^{*}$ \\
\hline
\end{tabular}


Table 4. Cont.

\begin{tabular}{ccc}
\hline Physiological Characteristics & T. ghanense & T. tomentosum \\
\hline 5 & $61.0 \pm 1.7^{*}$ & $67.6 \pm 0.6^{*}$ \\
\hline 6 & $53.3 \pm 2.8^{*}$ & $63.0 \pm 0.0^{*}$ \\
\hline 7 & $51.6 \pm 2.8^{*}$ & $42.0 \pm 1.0^{*}$ \\
\hline 8 & $51.0 \pm 1.7^{*}$ & $36.0 \pm 0.0^{*}$ \\
\hline $\begin{array}{c}\text { Decomposition of cellulose, } \% \\
\text { Decomposition of lignin, } \%\end{array}$ & $32.7 \pm 1.3^{*}$ & $25.6 \pm 0.9^{*}$ \\
\hline Enzymatic activity: & $11.0 \pm 0.8^{*}$ & $14.2 \pm 0.7^{*}$ \\
\hline endoglucanase, $\%$ & & $10.8 \pm 1.4^{*}$ \\
\hline peroxidase, a.u./g & $120.6 \pm 2.8^{*}$ & $90.0 \pm 4.2^{*}$ \\
\hline tyrosinase, c.u./g & $106.0 \pm 1.4^{*}$ & $0.72 \pm 0.0$ \\
\hline laccase, a.u. $/ g$ & $0.033 \pm 0.0$ & $0.004 \pm 0.0$ \\
\hline
\end{tabular}

Moreover, the studied strains demonstrated different abilities for decomposition of organic matter. The results showed that $T$. ghanense was more effective in the decomposition of cellulose $(p=0.0002)$ (Table 4$)$. Its endoglucanase activity was 11.1-fold higher compared to that of T. tomentosum; a significant difference was observed ( $p=0.0001)$. A statistically significant difference showed that T. tomentosum is more suitable for lignin degradation than T. ghanense $(p=0.0001)$. There were no significant differences in tyrosinase activity among Trichoderma species.

\subsection{The Chemical Properties and CM-Cellulase Activity of Soil}

Soils from different land-use systems (grassland $1 S$ and arable soil 2S) were selected for the experiment (Table 1). Soil chemical analysis showed that grassland $1 S$ was more productive than arable soil $2 \mathrm{~S}$, as it was richer (by nearly two-fold) in mobile humic substances with higher content of mobile humic and fulvic acids. Both soils had nearneutral pH (6.92 in the grassland $1 \mathrm{~S}$ and 6.83 in arable soil 2S), which was favorable for the growth of cereals [44]. The studied grassland $1 S$ was richer in organic carbon, but arable soil $2 \mathrm{~S}$ showed higher amounts of mobile $\mathrm{P}_{2} \mathrm{O}_{5}$ and mobile $\mathrm{K}_{2} \mathrm{O}$, which usually depend on the soil use and plants grown.

Before the experiment, the CM-cellulase activity of original soil and the number of fungi were estimated. The CM-cellulase activity of soil was $456.7 \pm 3.76 \mu \mathrm{g} \mathrm{GE} \mathrm{g}^{-1} \cdot \mathrm{dm} \cdot 24 \mathrm{~h}^{-1}$ in grassland $1 \mathrm{~S}$ and $100.4 \pm 2.56 \mu \mathrm{g} \mathrm{GE} \mathrm{g}^{-1} \cdot \mathrm{dm} \cdot 24 \mathrm{~h}^{-1}$ in arable soil $2 \mathrm{~S}$, which was 4.5 -fold lower than the level in grassland 1S. The number of cultivable fungi was $14.81 \times 10_{4} \mathrm{CFU} / \mathrm{g}$ in grassland $1 \mathrm{~S}$ and $5.98 \times 10^{4} \mathrm{CFU} / \mathrm{g}$ in arable soil 2S. Moreover, no Trichoderma spp. were isolated from the soils by the serial dilution method (at dilution $10^{3}$ ) before inoculation.

After 14 days of inoculation, the changes in chemical properties of the rhizospheric soil were activated by the fungal inoculum, as shown in Tables 5 and 6 .

Different parameter values of the inoculated soils and controls were uncertain (the differences were not more than $12 \%$ ), which could be due to the short time of the experiment.

The statistical analysis showed that the properties of the soil inoculated with the complex of Trichoderma resembled the original soil features after 14 days of inoculation (Figure 3). The grassland $1 S$ samples inoculated with monocultures were closer to the control soil variant. The analyzed characteristics of all variants of inoculated arable soil $2 \mathrm{~S}$ were similar to each other and different from the initial and control soil. The selected characteristics of the soils determined $79 \%$ of data variability for PCA. The chemical properties of the grassland $1 S$ and arable soil $2 S$ were significantly different. All characteristics that define soil organic matter (soil organic carbon, mobile humic substances, mobile humic and fulvic acids) were strongly intercorrelated with the CM-cellulase activity of the soil. 
Table 5. The chemical properties of grassland $1 \mathrm{~S}$ after 14 days of inoculation. Numbers followed by "*” indicate significant differences $(p<0.05)$.

\begin{tabular}{|c|c|c|c|c|}
\hline \multirow{3}{*}{$\begin{array}{c}\text { Chemical Properties } \\
\text { of Soil }\end{array}$} & \multicolumn{3}{|c|}{ Variants } & \multirow{2}{*}{$\begin{array}{l}\text { Control-Non } \\
\text { Inoculated Soil }\end{array}$} \\
\hline & T. ghanense & T. tomentosum & $\begin{array}{l}\text { T. ghanense + } \\
\text { T. tomentosum }\end{array}$ & \\
\hline & 1S & 1S & $1 \mathrm{~S}$ & $1 S$ \\
\hline SOC, $\%$ & $2.72 \pm 0.02$ & $2.68 \pm 0.06$ & $2.74 \pm 0.08$ & $2.75 \pm 0.18$ \\
\hline Humus, $\%$ & $4.69 \pm 0.07$ & $4.61 \pm 0.11$ & $4.73 \pm 0.11$ & $4.74 \pm 0.01$ \\
\hline Total N, \% & $0.208 \pm 0.001$ & $0.215 \pm 0.003 *$ & $0.207 \pm 0.008$ & $0.204 \pm 0.004$ \\
\hline $\mathrm{C} / \mathrm{N}$ & 13.1 & 12.5 & 13.2 & 13.5 \\
\hline $\begin{array}{l}\text { Exchangeable } \mathrm{P}_{2} \mathrm{O}_{5}, \\
\mathrm{mg} / \mathrm{kg}\end{array}$ & $71.90 \pm 0.57$ & $71.60 \pm 0.00 *$ & $71.60 \pm 0.70$ & $69.30 \pm 0.28$ \\
\hline $\begin{array}{c}\text { Exchangeable } \mathrm{K}_{2} \mathrm{O}, \\
\mathrm{mg} / \mathrm{kg}\end{array}$ & $124.50 \pm 0.41 *$ & $128.50 \pm 0.13 *$ & $124.20 \pm 0.08^{*}$ & $135.49 \pm 0.14$ \\
\hline $\begin{array}{l}\text { Labile water-soluble } \\
\text { carbon, } \mathrm{C}_{\mathrm{H} 2 \mathrm{O}}, \mathrm{g} / \mathrm{kg}\end{array}$ & $0.268 \pm 0.019$ & $0.275 \pm 0.026$ & $0.314 \pm 0.012$ & $0.291 \pm 0.019$ \\
\hline $\begin{array}{l}\text { Mobile humic } \\
\text { substances, \% }\end{array}$ & $0.406 \pm 0.08$ & $0.434 \pm 0.004$ & $0.422 \pm 0.014$ & $0.426 \pm 0.013$ \\
\hline Mobile humic acids, \% & $0.190 \pm 0.001$ & $0.179 \pm 0.004^{*}$ & $0.198 \pm 0.004^{*}$ & $0.188 \pm 0.003$ \\
\hline Mobile fulvic acids, $\%$ & $0.216 \pm 0.012 *$ & $0.255 \pm 0.008$ & $0.224 \pm 0.003$ & $0.238 \pm 0.004$ \\
\hline $\mathrm{pH}$ & $7.08 \pm 0.01 *$ & $7.02 \pm 0.01 *$ & $7.02 \pm 0.014$ & $7.00 \pm 0.00$ \\
\hline $\begin{array}{l}\text { CM-cellulase activity, } \\
\mu \mathrm{g} \mathrm{GE} \mathrm{g}^{-1} \cdot \mathrm{dm} \cdot 24 \mathrm{~h}^{-1}\end{array}$ & $896.00 \pm 3.46$ & $930.20 \pm 1.91 *$ & $849.40 \pm 7.20^{*}$ & $897.60 \pm 2.622$ \\
\hline
\end{tabular}

Table 6. The chemical properties of arable soil $2 \mathrm{~S}$ after 14 days of inoculation. Numbers followed by "*" indicate significant differences $(p<0.05)$.

\begin{tabular}{|c|c|c|c|c|}
\hline \multirow{3}{*}{$\begin{array}{l}\text { Chemical Properties } \\
\text { of Soil }\end{array}$} & \multicolumn{3}{|c|}{ Variants } & \multirow{2}{*}{$\begin{array}{l}\text { Control-Non } \\
\text { Inoculated Soil }\end{array}$} \\
\hline & T. ghanense & T. tomentosum & $\begin{array}{l}\text { T. ghanense + } \\
\text { T. tomentosum }\end{array}$ & \\
\hline & $2 S$ & $2 S$ & $2 \mathrm{~S}$ & $2 S$ \\
\hline SOC, \% & $1.39 \pm 0.05$ & $1.43 \pm 0.01$ & $1.33 \pm 0.01$ & $1.38 \pm 0.05$ \\
\hline Humus, \% & $2.40 \pm 0.06$ & $2.46 \pm 0.01$ & $2.30 \pm 0.06$ & $2.38 \pm 0.11$ \\
\hline Total N, \% & $0.105 \pm 0.001$ & $0.109 \pm 0.001$ * & $0.114 \pm 0.001$ & $0.123 \pm 0.004$ \\
\hline $\mathrm{C} / \mathrm{N}$ & 13.2 & 13.1 & 11.7 & 11.2 \\
\hline $\begin{array}{l}\text { Exchangeable } \mathrm{P}_{2} \mathrm{O}_{5}, \\
\mathrm{mg} / \mathrm{kg}\end{array}$ & $134.40 \pm 1.20$ & $130.60 \pm 1.13$ & $129.60 \pm 0.14$ & $127.40 \pm 2.69$ \\
\hline $\begin{array}{c}\text { Exchangeable } \mathrm{K}_{2} \mathrm{O}, \\
\mathrm{mg} / \mathrm{kg}\end{array}$ & $163.40 \pm 0.68 *$ & $155.70 \pm 0.70$ * & $149.90 \pm 0.68 *$ & $178.30 \pm 1.34$ \\
\hline $\begin{array}{l}\text { Labile water-soluble } \\
\text { carbon, } \mathrm{C}_{\mathrm{H} 2} \mathrm{O}, \mathrm{g} / \mathrm{kg}\end{array}$ & $0.194 \pm 0.015$ & $0.197 \pm 0.013$ & $0.182 \pm 0.019^{*}$ & $0.199 \pm 0.021$ \\
\hline $\begin{array}{l}\text { Mobile humic } \\
\text { substances, \% }\end{array}$ & $0.146 \pm 0.006$ & $0.151 \pm 0.004$ & $0.144 \pm 0.006$ & $0.157 \pm 0.003$ \\
\hline Mobile humic acids, $\%$ & $0.050 \pm 0.001$ & $0.061 \pm 0.002$ & $0.051 \pm 0.001 *$ & $0.059 \pm 0.000$ \\
\hline Mobile fulvic acids, $\%$ & $0.096 \pm 0.001$ & $0.090 \pm 0.004$ & $0.093 \pm 0.004$ & $0.098 \pm 0.001$ \\
\hline $\mathrm{pH}$ & $7.13 \pm 0.01 *$ & $7.15 \pm 0.00$ & $7.13 \pm 0.01 *$ & $7.28 \pm 0.00$ \\
\hline $\begin{array}{l}\text { CM-cellulase activity, } \mu \mathrm{g} \\
\mathrm{GE}^{-1} \cdot \mathrm{dm} \cdot 24 \mathrm{~h}^{-1}\end{array}$ & $114.80 \pm 3.79 *$ & $324.60 \pm 3.47^{*}$ & $332.80 \pm 4.30 *$ & $114.50 \pm 3.93$ \\
\hline
\end{tabular}




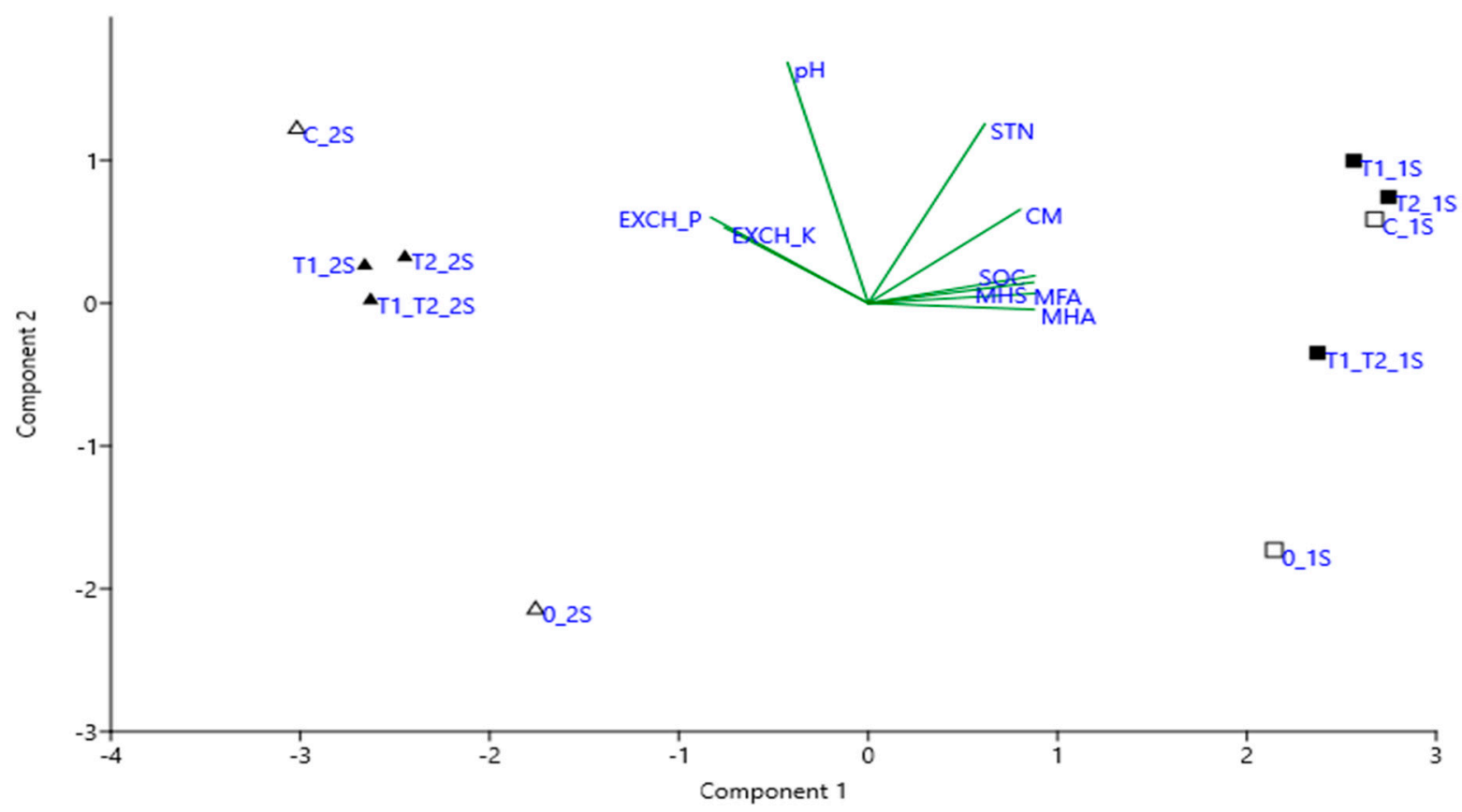

Figure 3. PCA diagrams for variables in experiment on Trichoderma spp. inoculated soil originated from different land-use systems. 0_1S—original grassland, C_1S—grassland non-inoculated, T1_1S— grassland inoculated with T. tomentosum, T2_1S_-grassland inoculated with T. ghanense, T1_T2_1S inoculated with the complex T. tomentosum + T. ghanense, 0_2S_original arable soil, C_2S_arable soil non-inoculated, T1_2S—arable soil inoculated with T. tomentosum, T2_2S—arable soil inoculated with T. ghanense, T1_T2_2S-inoculated with the complex T. tomentosum + T. ghanense. SOC-soil organic carbon, MHA — mobile humic acid, MFA — mobile fulvic acid, MHS — mobile humic substances, $\mathrm{CM}-\mathrm{CM}$-cellulase activity of soil, STN—-total N, pH—soil pH, EXCH_K—exchangeable $\mathrm{K}_{2} \mathrm{O}, \mathrm{EXCH} \mathrm{P}$ exchangeable $\mathrm{P}_{2} \mathrm{O}_{5}$.

Inoculation with Trichoderma spp. had a significant stimulating effect on soil enzyme activity. The most significant effect on this activity was found in the arable soil $2 S$ when T. tomentosum and the complex T. tomentosum + T. ghanense were applied (Tables 5 and 6, Figure 3). It was nearly 3-fold higher (2.8-fold and 2.9-fold, respectively) compared to control; at this time, a significant difference was observed.

Surprisingly, we did not observe an expected (as in arable soil 2S) change in the soil properties of grassland 1S. After 14 days of inoculation, the highest CM-cellulase activity of soil was with T. tomentosum, but it was only 1.03-fold higher than in the grassland $1 S$ control.

\subsection{The Evaluation of Rye Seedling Growth}

In our experiment, the length of shoot and root of early rye seedlings and their total weight determined the impact of soil on the plant growth promotion ability of different Trichoderma strains. The data are presented in Figures 4 and 5. Our study results indicated that the plant growth promotion ability of Trichoderma spp. in grassland $1 \mathrm{~S}$ was different from that in arable soil $2 S$. 

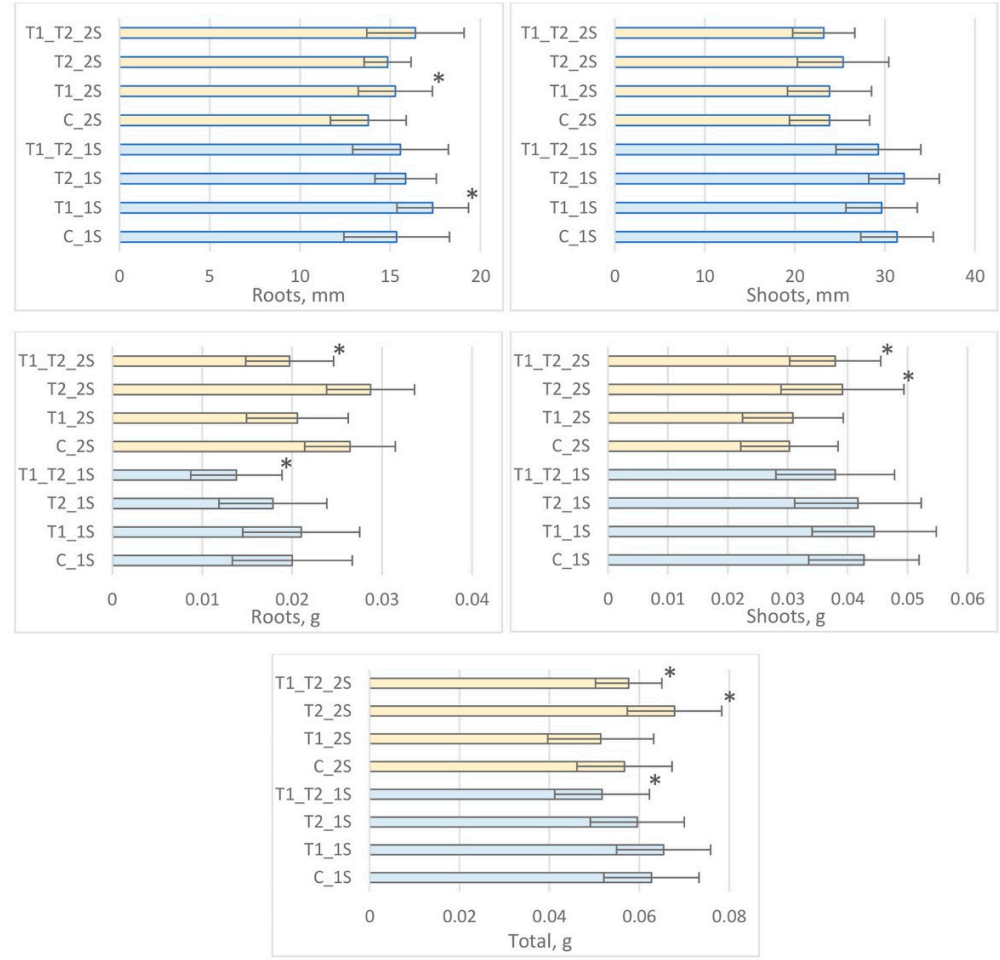

Figure 4. Effects of inoculation with Trichoderma spp. on vegetative plant growth. C_1S-grassland non-inoculated, T1_1S_grassland inoculated with T. tomentosum, T2_1S—grassland inoculated with T. ghanense, T1_T2_1S_-grassland inoculated with the complex T. tomentosum + T. ghanense, C_2S_arable soil non-inoculated, T1_2S—arable soil inoculated with T. tomentosum, T2_2S—arable soil inoculated with T. ghanense, T1_T2_2S—arable soil inoculated with the complex T. tomentosum + T. ghanense. * above the bars indicate significant differences.
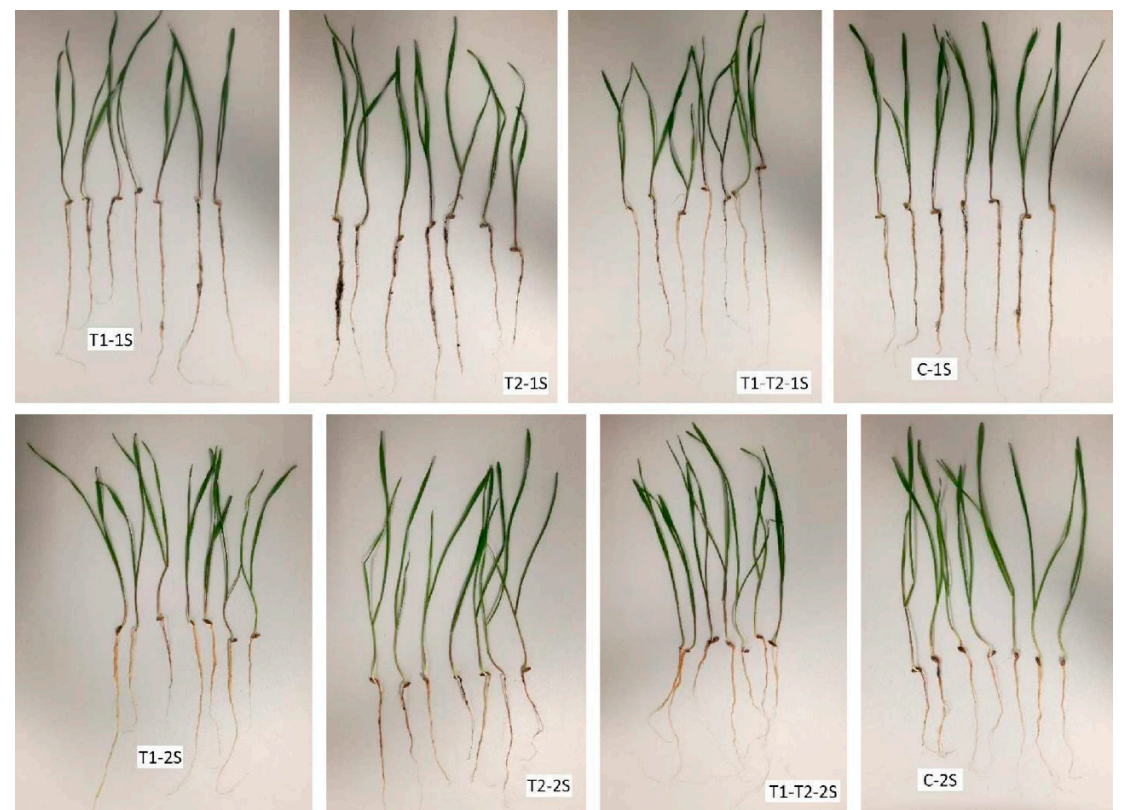

Figure 5. The early seedlings of rye after harvest. T1-1S - grassland inoculated with T. tomentosum, T2-1S-grassland inoculated with T. ghanense, T1-T2-1S-grassland inoculated with the complex T. tomentosum + T. ghanense, C-1S-grassland non-inoculated, T1-2S-arable soil inoculated with T. tomentosum, T2-2S-arable soil inoculated with T. ghanense, T1-T2-2S - arable soil inoculated with the complex T. tomentosum $+T$. ghanense, C-2S-arable soil non-inoculated. 
The greatest beneficial effect of T. tomentosum on rye was noticed in grassland $1 S$ (Figure 4). A statistically significant difference was established for the length of the roots of rye in grassland with the inoculation of T. tomentosum $(p=0.005)$. The total weight of the rye seedling was 3.2\% larger in grassland than in non-inoculated soil (control), though a significant difference was not observed $(p=0.321)$. Furthermore, while the weight of the shoot and root of the rye seedlings was larger compared to the control, unfortunately these differences were not significant ( $p=0.345$ and $p=0.331$, respectively).

As shown in Figure 4, the plant growth promotion ability of T. ghanense was detected in arable soil 2S. The total weight of rye seedlings was $19.3 \%$ larger in this variant compared to that of the control (significant differences $p=0.014$ ). Differences in the length of shoots and roots between inoculated samples and the control were uncertain (no significant differences were observed $p=0.241$ and $p=0.143$, respectively) when $T$. ghanense was applied.

The use of inoculum of complex T. tomentosum $+T$. ghanense in grassland $1 S$ and arable soil $2 S$ did not have a growth promotion effect on the rye seedlings (Figure 4 ). The total weight of the rye seedlings was less in grassland $1 S$ compared to the control, and a significant difference was observed $(p=0.040)$. A statistically significant difference was established in arable soil 2S: the shoots were larger in weight $(p=0.004)$

\section{Discussion}

The successful and efficient use of bioproducts for plant growth promotion depends on the active development of fungi in the substrates. Abiotic factors, as well as biotic, could promote or suppress the action of fungi in the soil. Therefore, the physiological characteristics of fungi and their ability to survive and adapt to various environmental conditions are of great interest. Muniappan and Muthukumar [45] observed the importance of $\mathrm{pH}$ values and detected a negative correlation between Trichoderma koningii abundance and soil pH. Moreover, Caporale et al. [25] demonstrated the importance of soil quality to the effect of different Trichoderma strains on Brassica rapa growth.

Our studied fungi had different optimum growth conditions and enzymatic activity. It was observed that T. tomentosum could develop better at lower temperatures than T. ghanense, but the latter showed optimal growth under a broader range of $\mathrm{pH}$. Moreover, T. ghanense was a better decomposer of cellulose, and T. tomentosum a better decomposer of lignin. Therefore, we were expecting that their complex would be more viable in different soil qualities and more effective in the mineralization of organic matter than a single strain.

In our experiment, soils with different chemical properties were chosen. The chemical analysis of the studied soils demonstrated the impoverishment of arable soil $2 \mathrm{~S}$, as it had less humic substances and organic carbon than grassland 1S. Furthermore, the analysis of the soil enzyme that participates in decomposition of organic matter showed that the CM-cellulase activity was weaker in arable soil $2 \mathrm{~S}$ compared with grassland $1 \mathrm{~S}$. The CMcellulase activity of soil, as the main cellulolytic enzyme, indicates intensive mineralization of organic matter, which is carried out by microorganisms. The higher the level of CMcellulase activity, the higher the degree of organic matter mineralization, which provides plants with more nutrients for growth [46]. We hypothesized that the enrichment of soil by fungi with cellulolytic activity could increase CM-cellulase activity and improve the soil with nutrients. Our results demonstrated the dependence of CM-cellulose activity of soil on inoculation with Trichoderma spp. The most significant increase in this activity was detected in arable soil $2 S$, compared with the control, when T. tomentosum and the complex T. tomentosum + T. ghanense were applied. The possible explanation for this might be a lower number of microorganisms and weaker competition with native microorganisms. Grassland microbiome is richer in number and species of microorganisms. Therefore, it was more difficult for Trichoderma inoculum to establish its ecological niche. The CM-cellulase activity of soil depends not only on Trichoderma activity because other microorganisms also play an important role in this process of cellulose decomposition [44]. As such, interactions between microorganisms can be significant. 
Debnath et al. [47] distinguished between the plant growth promoting ability of Trichoderma and its role as a biofertilizer, although they did not define strict limits between these two characteristics. The studies on the Trichoderma action mechanism showed that it produced active cellulolytic enzymes that resulted in the mineralization of organic matter. At the same time, it could enhance the uptake of nutrients and root hair development.

The promoting effect of fungi such as Trichoderma on plant growth is well known and described by different researchers $[19,44,48,49]$. Application of Trichoderma inoculum at an early stage of crop growth permits one to maximize the benefits in terms of root development and nutrient uptake [3]. However, there is not enough data on the behavior of this fungus in different soils and in the natural environment [39]. In nature, a consortium of microorganisms exists in soil, and their interactions could affect the production of different metabolites [21]. These relationships are very important when Trichoderma is expected to be used as a plant growth promoter in soil.

In our experiment, the impact of soil on the growth-promoting ability of different Trichoderma strains and their complexes was determined by length of shoots and roots of the early rye seedlings and their total weight. Our results showed that the effect of Trichoderma inoculation was different in grassland $1 S$ and arable soil $2 S$ and depended on the species of fungi. The beneficial effects of T. tomentosum on early rye seedling growth was noted in the grassland (1S), while that of T. ghanense was noted in the arable soil (2S).

Root measurements clearly demonstrated the growth-promoting effects of indigenous Trichoderma strains. Statistically significant differences were estimated between the rye roots in grassland inoculated with T. tomentosum $(p=0.005)$ and roots in the control. Longer roots improve nutrient uptake by the plant and ensure further successful growth. The interaction between plant and Trichoderma spp. successfully regulates root architecture and increases the length of lateral and primary roots, resulting in effective nutrient uptake by the plant [20]. Trichoderma spp. releases into the rhizosphere auxins, small peptides, volatiles, and other active metabolites that promote root branching and nutrient uptake capacity, thereby boosting plant growth and yield [3]. Several reports have shown that Trichoderma spp. colonize plant roots, penetrate the epidermis, and produce various compounds that affect the plant $[7,18,44,50]$. This could explain the effect of inoculum foremost on the roots of rye in the short-term experiment. Our results showing the different action of indigenous Trichoderma strains on rye seedling growth correlated with the established effects of T. harzianum and T. virens on Pinus sylvestris seedlings [19]. Comparing the obtained results with other scientific reports, the differences in the degree of the growth-promoting effect on fungi were noticed. When the experiments were performed in sterile soil, the promoting effect on plant growth was more pronounced. For example, T. longibrachiatum increased tomato root volume by $96 \%$ [17]. In our experiment, the highest increase in the total weight of early rye seedlings was $19.3 \%(p=0.014)$. However, our other findings were consistent with observations by Hajieghrari and Mohammadi [51] that some Trichoderma strains capable of colonizing roots showed no significant effect on wheat seedling parameters. Moreover, our results showed that the shoots and roots of the rye seedlings did not always correlate with seedling dry weight. Tančić-Živanov et al. [52] observed similar results with the effect of some Trichoderma isolates on early pepper seedlings.

Contrary to our expectations, a growth-promoting effect on early rye seedlings by the complex of Trichoderma strains was detected only in arable soil $2 S$. Though the weight of shoots was larger compared to the control, the total weight of the rye seedlings was not larger.

According to these data, our results contradicted the opinion expressed by Vassilev et al. [21] that microbial co-cultivation could be successfully used as a biofertilizer. These results demonstrated that selection of the strains for use is very important.

However other factors could have an impact on plant growth when the experiment is performed in the soil environment. For example, the humic substances in grassland could be one of the factors that stimulated the growth of seedlings [53,54]. On the other hand, biological and physiological properties such as the competitive abilities of the inoculum 
are very important, as highlighted in an article published by Singh et al. [44]. Since the dependence of the growth-promoting ability of Trichoderma spp. inoculum on the soil type could explain the inefficiency of bio-product in some cases, the selection of a suitable strain of fungi is still of great importance. The complexity of the phenomenon of Trichoderma growth-promoting ability requires thorough studies.

\section{Conclusions}

In the present study, the indigenous Trichoderma species with different physiological characteristics were tested as biostimulants on the early rye seedlings grown in the sustained grassland and arable soil. The study showed not only that the physiological characteristics of fungi play an important role but also the quality of the soil had an impact on plant growth promotion. Rye seedling root growth was enhanced when T. tomentosum was applied in the sustainable grassland $(p=0.005)$, whereas in the arable soil an increase in total weight and shoot weight of the rye seedlings was observed when T. ghanense was used ( $p=0.014$ and $p=0.024$ ). The expected beneficial effect of Trichoderma spp. complex on rye growth promotion was not observed in any tested soil. The obtained results could find application in the development of new and efficient biostimulants and potentially practical strategies for sustainable management.

Author Contributions: D.B., V.R. and A.P. conceived the experiment and methodology. V.R., D.B. and J.Š. (Jurgita Švedienè) performed the experiment on rye seedling growth and writing-original draft, review and editing. A.K. performed molecular identification. A.Š. and J.Š. (Jonas Šlepetys) performed soil chemical analysis. I.B. and G.V. performed the statistical analysis. All authors have read and agreed to the published version of the manuscript.

Funding: This research received no external funding.

Institutional Review Board Statement: Not applicable.

Informed Consent Statement: Not applicable.

Data Availability Statement: Data available from the corresponding author J.Š. on request.

Conflicts of Interest: The authors declare no conflict of interest.

\section{References}

1. Meena, R.S.; Kumar, S.; Datta, R.; Lal, R.; Vijayakumar, V.; Brtnicky, M. Impact of agrochemicals on soil microbiota and management: A Review. Land 2020, 9, 34. [CrossRef]

2. Lugtenberg, B.J.J.; Malfanova, N.; Kamilova, F.; Berg, G. Plant growth promotion by microbes. In Molecular Microbial Ecology of the Rhizosphere, 1st ed.; de Bruijn, F., Ed.; John Wiley \& Sons: Hoboken, NJ, USA, 2013; Volume 2, pp. 559-573.

3. López-Bucio, J.; Pelagio-Flores, R.; Herrera-Estrella, A. Trichoderma as biostimulant: Exploiting the multilevel properties of a plant beneficial fungus. Sci. Hortic. 2015, 196, 109-123. [CrossRef]

4. Hyde, K.D.; Xu, J.; Rapior, S.; Jeewon, R.; Lumyong, S.; Niego, A.G.T.; Abeywickrama, P.D.; Aluthmuhandiram, J.V.; Brahamanage, R.S.; Brooks, S.; et al. The amazing potential of fungi: 50 ways we can exploit fungi industrially. Fungal Divers. 2019, 97, 1-136. [CrossRef]

5. Aamir, M.; Rai Kumar, K.; Zehra, A.; Dubey Kumar, M.; Kumar, S.; Shukla, V.; Upadhyay, R.S. Microbial bioformulation-based plant biostimulants: A plausible approach toward next generation of sustainable agriculture. In Microbial Endophytes Functional Biology and Applications; Kumar, A., Radhakrishnan, E.K., Eds.; Woodhead Pub Ltd.: Cambridge, UK, 2020; pp. $195-225$.

6. Castiglione, A.M.; Mannino, G.; Contartese, V.; Bertea, C.M.; Ertani, A. Microbial biostimulants as response to modern agriculture needs: Composition, role and application of these innovative products. Plants 2021, 10, 1533. [CrossRef]

7. Saba, H.; Vibhash, D.; Manisha, M.; Prashant, K.S.; Farhan, H.; Tauseef, A. Trichoderma-A promising plant growth stimulator and biocontrol agent. Mycosphere 2014, 3, 524-531. [CrossRef]

8. Nabi, S.U.; Malik, G.; Sharma, A. Trichoderma harzianum: A potential bioagent and plant growth promoter. EC Microbiol. 2018, $14,147$.

9. Rajkonda, J.N.; Bhale, U.N. Influence of culture media on the growth of Trichoderma species. In Proceedings of the National Conference on Biodiversity: Prospects and Potentials at: Dept of Botany, S.M. Dnyandeo Mohekar Mahavidyala, Kalamb, Osmanabad, India, 28-29 December 2014; pp. 113-120.

10. Asad, S.A.; Tabassum, A.; Hameed, A.; Hassan, F.U.; Afzal, A.; Khan, S.A.; Ahmed, R.; Shahzad, M. Determination of lytic enzyme activities of indigenous Trichoderma isolates from Pakistan. Braz. J. Microbiol. 2015, 46, 1053-1064. [CrossRef]

11. Cherkupally, R.; Amballa, H.; Reddy, B.N. In vitro screening for enzymatic activity of Trichoderma species for biocontrol potential. Ann. Plant Sci. 2017, 6, 1784-1789. [CrossRef] 
12. Novy, V.; Nielsen, F.; Seiboth, B.; Nidetzky, B. The influence of feedstock characteristics on enzyme production in Trichoderma reesei: A review on productivity, gene regulation and secretion profiles. Biotechnol. Biofuels 2019, 12, 238. [CrossRef]

13. Hasan, S. Potential of Trichoderma sp. in bioremediation: A review. Int. J. Appl. Eng. Res. 2016, 3, 776-779.

14. Banaay, C.G.B.; Cuevas, V.C.; Cruz, C.M.V. Trichoderma ghanense promotes plant growth and controls disease caused by Pythium arrhenomanes in seedlings of aerobic rice variety Apo. Philipp. Agric. Sci. 2012, 95, 175-184.

15. Talla, S.G.; Raju, A.S.R.; Karri, S.; Kumar, Y.S. Production and antagonistic effect of Trichoderma spp. on pathogenic microorganisms (Botrytis cinerea, Fusarium oxysporum, Macrophomina phasealina and Rhizoctonia solani). Afr. J. Biotechnol. 2015, 14, 668-675.

16. Herrera-Jiménez, E.; Alarcón, A.; Larsen, J.; Ferrera-Cerrato, R.; Cruz-Izquierdo, S.; Ferrera-Rodríguez, M.R. Comparative effects of two indole-producing Trichoderma strains and two exogenous phytohormones on the growth of Zea mays L., with or without tryptophan. J. Soil Sci. Plant Nut. 2018, 18, 188-201. [CrossRef]

17. Zhang, S.; Gan, Y.; Xu, B. Application of plant-growth-promoting fungi Trichoderma longibrachiatum T6 enhances tolerance of wheat to salt stress through improvement of antioxidative defence system and gene expression. Front. Plant Sci. $2016,7,1405$. [CrossRef] [PubMed]

18. Alwhibi, M.S.; Hashem, A.; Abd_Allah, E.F.; Alqarawi, A.A.; Soliman, D.W.K.; Wirth, S.; Wirth, S.; Egamberdieva, D. Increased resistance of drought by Trichoderma harzianum fungal treatment correlates with increased secondary metabolites and proline content. J. Integr. Agric. 2017, 16, 1751-1757.

19. Khoshmanzar, E.; Aliasgharzad, N.; Neyshabouri, M.R.; Khoshru, B.; Arzanlou, M.; Asgari Lajayer, B. Effects of Trichoderma isolates on tomato growth and inducing its tolerance to water-deficit stress. Int. J. Environ. Sci. Technol. 2020, 17, 869-878. [CrossRef]

20. Zin, N.A.; Badaluddin, N.A. Biological functions of Trichoderma spp. for agriculture applications. Ann. Agric. Sci. 2020, 65, 168-178. [CrossRef]

21. Vassilev, N.; Vassileva, M.; Lopez, A.; Martos, V.; Reyes, A.; Maksimovic, I.; Eichler-Löbermann, B.; Malusà, E. Unexploited potential of some biotechnological techniques for biofertilizer production and formulation. Appl. Microbiol. Biotechnol. 2015, 99, 4983-4996. [CrossRef]

22. Halifu, S.; Deng, X.; Song, X.; Song, R. Effects of two Trichoderma strains on plant growth, rhizosphere soil nutrients, and fungal community of Pinus sylvestris var. mongolica annual seedlings. Forests 2019, 10, 758

23. Woo, S.L.; Ruocco, M.; Vinale, F.; Nigro, M.; Marra, R.; Lombardi, N.; Pascale, A.; Lanzuise, S.; Manganiello, G.; Lorito, M. Trichoderma-based products and their widespread use in agriculture. Open Mycol. J. 2014, 8, 71-126. [CrossRef]

24. Compant, S.; Samad, A.; Faist, H.; Sessitsch, A. A review on the plant microbiome: Ecology, functions, and emerging trends in microbial application. J. Adv. Res. 2019, 19, 29-37. [CrossRef]

25. Caporale, A.G.; Vitaglione, P.; Troise, A.D.; Pigna, M.; Ruocco, M. Influence of three different soil types on the interaction of two strains of Trichoderma harzianum with Brassica rapa subsp. sylvestris cv. esculenta, under soil mineral fertilization. Geoderma 2019, 350, 11-18. [CrossRef]

26. Germida, J.J.; de Freitas, J.R. Cultural methods for soil and root-associated microorganisms. In Soil Sampling and Analysis, 2nd ed.; Carter, M.R., Gregorich, E.G., Eds.; CRC Press Taylor \& Francis Group: Sound Parkway, NW, USA, 2007; pp. $341-354$.

27. Chaverri, P.; Castlebury, L.A.; Barrie, E.O.; Gary, J.S. Hypocrea/Trichoderma: Species with conidiophore elongations and green conidia. Mycologia 2003, 95, 1100-1140. [CrossRef]

28. Samuels, G.J.; Ismaiel, A.; Mulaw, T.B.; Szakacs, G.; Druzhinina, I.S.; Kubicek, C.P.; Jaklitsch, W.M. The Longibrachiatum Clade of Trichoderma: A revision with new species. Fungal Divers. 2012, 55, 77-108. [CrossRef]

29. White, T.J.; Bruns, T.; Lee, S.; Taylor, J. Amplification and direct sequencing of fungal ribosomal RNA genes for phylogenetics. In PCR Protocols: A Guide to Methods and Applications; Innis, M.A., Gelfand, D.H., Sninsky, S.S., White, T.J., Eds.; Academic Press: New York, NY, USA, 1990; pp. 315-322.

30. Nikolcheva, L.G.; Bärlocher, F. Taxon-specific fungal primers reveal unexpectedly high diversity during leaf decomposition in a stream. Mycol. Prog. 2004, 3, 41-49. [CrossRef]

31. O'Donnell, K.; Kistler, H.C.; Cigelnik, E.; Ploetz, R.C. Multiple evolutionary origins of the fungus causing Panama disease of banana: Concordant evidence from nuclear and mitochondrial gene genealogies. Proc. Natl. Acad. Sci. USA 1998, 95, $2044-2049$. [CrossRef]

32. Tamura, K.; Stecher, G.; Kumar, S. MEGA 11: Molecular Evolutionary Genetics Analysis Version 11. Mol. Biol. Evol. 2021, 38 , 3022-3027. [CrossRef] [PubMed]

33. Nei, M.; Kumar, S. Molecular Evolution and Phylogenetics; Oxford University Press: New York, NY, USA, 2000.

34. Felsenstein, J. Confidence limits on phylogenies: An approach using the bootstrap. Evolution 1985, 39, 783-791. [CrossRef]

35. Bilai, V.I. Methods of Experimental Mycology; Naukova Dumka: Kiev, Ukraine, 1982; p. 550.

36. Ravin, H.A.; Harward, M.D. Rapid test for hepatolenticular degeneration. Lancet 1965, 267, 726-727. [CrossRef]

37. Jermakov, A.I.; Arasimovitsh, V.V.; Jarosh, N.P.; Peruanskij, U.A.; Lukovnikova, G.A.; Ikonnikova, M.I. Methods of Plant Biochemical Research; Agropromizdat: Leningrad, Russia, 1987; p. 430.

38. Chudiakova, C.K. Determination of the lignin content in fodder and green crop. Selskochoziaistvenaja Biol. 1984, 8, 120-124.

39. Nikitin, B.A. Method for soil humus determination. Agric. Chem. 1999, 3, 156-158.

40. Šlepetienė, A.; Kadžiulienè, Ž.; Feizienė, D.; Liaudanskienè, I.; Amalevičiūtè-Volungè, K.; Šlepetys, J. The distribution of organic carbon, its forms and macroelements in agricultural soils. Zemdirbyste 2020, 107, 291-300. [CrossRef] 
41. Ponomareva, V.V.; Plotnikova, T.A. Humus and Soil Formation; Nauka: Leningrad, Russia, 1980.

42. Schinner, F.; Öhlinger, R.; Kandeler, E.; Margesin, R. Methods in Soil Biology; Springer-Verlag: Berlin/Heidelberg, Germany, $1996 ;$ p. 416.

43. ISO 11269-2:2012 Soil Quality_Determination of Pollutants on Soil Flora. Part 2: Effect of Contaminated Soil on the Emergence and Early Growth of Higher Plants. Available online: www.iso.org/standard/51382.html (accessed on 14 January 2022).

44. Singh, D.P.; Singh, H.B.; Prabha, R. Microbial Inoculants in Sustainable Agricultural Productivity; Functional Applications; Springer: New Delhi, India, 2016; Volume 2, p. 308.

45. Muniappan, V.; Muthukumar, T.M. Influence of crop species and edaphic factors on the distribution and abundance of Trichoderma in Alfisol soils of southern India. Acta Bot. Croat. 2014, 73, 37-50. [CrossRef]

46. van Elsas, J.D.; Jansson, J.K.; Trevors, J.T. Modern Soil Microbiology, 2nd ed.; CRC Press Taylor and Francis Group Boca Raton: Boca Raton, FL, USA, 2006; p. 698.

47. Debnath, S.; Chakraborty, G.; Dutta, S.S.; Chaudhuri, S.R.; Das, P.; Saha, A.K. Potential of Trichoderma species as biofertilizer and biological control on Oryza sativa L. cultivation. Biotecnol. Veg. 2020, 20, 1-6.

48. Bononi, L.; Chiaramonte, J.B.; Pansa, C.C.; Moitinho, M.A.; Melo, I.S. Phosphorus-solubilizing Trichoderma spp. from Amazon soils improve soybean plant growth. Sci. Rep. 2020, 10, 2858. [CrossRef] [PubMed]

49. Ji, S.; Liu, Z.; Liu, B.; Wang, Y.; Wang, J. The effect of Trichoderma biofertilizer on the quality of flowering Chinese cabbage and the soil environment. Sci. Hortic. 2020, 262, 109069. [CrossRef]

50. Martínez-Medina, A.; Del Mar Alguacil, M.; Pascual, J.A.; van Wees, S.C.M. Phytohormone profiles induced by Trichoderma isolates correspond with their biocontrol and plant growth-promoting activity on melon plants. J. Chem. Ecol. 2014, 40, 804-815. [CrossRef]

51. Hajieghrari, B.; Mohammadi, M. Growth-promoting activity of indigenous Trichoderma isolates on wheat seed germination, seedling growth and yield. Aust. J. Crop Sci. 2016, 10, 1339-1347. [CrossRef]

52. Tančić-Živanov, S.; Medić-Pap, S.; Prvulovic, D. Effect of Trichoderma spp. on Growth Promotion and Antioxidative Activity of Pepper Seedlings. Braz. Arch. Biol. Technol. 2020, 63, e20180659. [CrossRef]

53. Cooper, R.J.; Liu, C.; Fisher, D.S. Influence of humic substances on rooting and nutrient content of creeping bentgrass. Crop Sci. 1998, 38, 1639-1644. [CrossRef]

54. Canellas, L.P.; Olivares, F.L. Physiological responses to humic substances as plant growth promoter. Chem. Biol. Technol. 2014, 1, 3. [CrossRef] 